\title{
THE CORRELATION BETWEEN KNOWLEDGE AND PERCEPTION OF YOUTH USERS OF VAPE TOWARDS VAPING BEHAVIOR IN BANGIL DISTRICT
}

\author{
Lu'lu'il Maqnun', Pudji Lestari*2 ${ }^{\mathbb{D}}$, Laksmi Wulandari ${ }^{3}$
}

${ }^{1}$ Faculty of Medicine, Universitas Airlangga, Indonesia, ${ }^{2}$ Department of Public Health-Preventive Medicine, Faculty of Medicine, Universitas Airlangga, Indonesia, ${ }^{3}$ Department of Pulmonology and Respiratory Medicine, Faculty of Medicine, Universitas Airlangga, Dr Soetomo General Academic Hospital, Indonesia

ABSTRACT
The use of e-cigarettes year by year increases among
adolescents. The increase correlates with their lack of
knowledge about e-cigarettes and the perception that e-
cigarettes are safer than conventional cigarettes. This research
aims to analyze the relationship between the level of knowledge
and perception of e-cigarettes to vaping behavior in adolescents
in Bangil, Pasuruan. This study was analytic observational with
a cross-sectional approach conducted from September until
October 2019. The subjects in this study were 76 respondents
selected by the purposive sampling method. The respondents
were recruited from 3 cafes in Bangil by distributing
questionnaires to those who met the inclusion criteria. The
independent variables are the respondent's knowledge level and
perception about e-cigarettes, while the dependent variable is
vaping behavior. The data has been analyzed with Spearman's
rho. From the analysis, there was a correlation between level of
knowledge and vaping behavior with p=0.019 (p<0.05) and
0.269 correlation coefficient. Also, a correlation between
perception and vaping behavior with p=0.000 (p<0.05) and
0.420 correlation coefficient. There was a correlation between
knowledge level and perception of e-cigarettes to vaping
behavior among adolescent users.

\section{ARTICLE HISTORY}

Received: October 20, 2020

Revised: December 21, 2020

Accepted: March 21, 2021

Published: June 30, 2021

(Online)

doi:

10.20473/jcmphr.v2i1.22685

\section{KEYWORDS}

Knowledge; perception; vaping behavior; e-cigarette; adolescent; tobacco addiction

\section{CORRESPONDING \\ AUTHOR}

Pudji Lestari

凹pudjilestari70@fk.unair.ac.id

Department of Public Health-

Preventive Medicine, Faculty of

Medicine, Universitas Airlangga,

Jl. Mayjend Prof. Dr. Moestopo

47, Surabaya, Indonesia

\section{INTRODUCTION}

Electric cigarette, known as vape or vapor, is a kind of cigarette that uses electricity from battery power to provide nicotine in the form of vapor or better known as the electronic nicotine delivery system (ENDS). The Ecigarette was originally produced as NRT (Nicotine Replacement Therapy), which is an alternative therapy for conventional cigarette addicts. ${ }^{1}$ Now, there is a change in the function of e-cigarettes, people use them without having a previous history of conventional smoking. The Centers for
Disease Control and Prevention (CDC), Food and Drug Administration (FDA), and Georgia State University stated that the number of adolescents who had never smoked conventional cigarettes but used ecigarettes tripled during 2011-2013. ${ }^{2}$ Meanwhile, the use of e-cigarettes among middle and high school students in the United States increased 7 times during 2011-2016. ${ }^{3}$

E-cigarette uses liquids containing nicotine with a mixture of propylene glycol (PG), vegetable glycerin, flavor enhancers, and other chemical substances. ${ }^{4}$ Effects of 
nicotine can cause neuro teratogenic and neurotoxic effects on adolescent's brain development. ${ }^{5}$ In addition, nicotine can also reduce focus and cognitive impairment, causing mood disorders in adolescents which results in long-term changes in emotional response, particularly increased anxiety and fear. PG aerosols produced from e-cigarettes can irritate the eyes and respiratory problems for users and non-users. ${ }^{6}$ Incomplete evaporation of propylene glycol and glycerin produces carcinogenic formaldehyde. The flavorings contained are reported to cause cytotoxic effects. ${ }^{7}$ Other substances such as carcinogenic nitrosamines are also found in e-cigarettes where the nitrosamine content is higher than in conventional cigarettes. ${ }^{8}$

There is still no data showing the number of e-cigarette users in Indonesia, especially in the regions. However, adolescents who vape are more likely to smoke conventional cigarettes in the future than those who do not. ${ }^{9}$ This may lead to increased use of conventional cigarettes in the future. In July 2018, the government legalized e-cigarettes so that users feel safe to use e-cigarettes. The government legalizes e-cigarettes by setting quite expensive excise fees. The imposition of excise fees is a way for the government to monitor the use of e-cigarettes in Indonesia. However, this legality is questionable because e-cigarettes do not meet safety standards. ${ }^{10}$ Because of the unclear safety regulations of existing dangers, the use of ecigarettes is increasingly widespread in Indonesia. Lack of information about ecigarettes can affect the level of knowledge and perception which causes e-cigarettes to be widely used, especially by teenagers. Therefore, this study aims to identify the level of knowledge and perceptions of vaping behavior specifically e-cigarette users in Bangil district.

\section{MATERIALS AND METHODS}

This study used an observational analytic method with a cross-sectional design. The population sampled were all adolescent vape users in Bangil using the purposive sampling method. The inclusion criteria were adolescents aged 18-24 years active user of e-cigarette. The total sample was 76 respondents, obtained between SeptemberOctober 2019 and were taken in 3 cafes in Bangil, they are Vape 456, Coklat Banget, and Sekawan. Researchers create a team that helps in collecting respondent data through questionnaires that have been tested for validity and reliability. Each respondent accompanied by one person (researcher or team) to prevent from committing fraud in filling the questionnaire. The questionnaire was filled in according to the order and was filled in by the respondents themselves. Researchers and the team only readout information for consent and informed consent. The independent variable was the respondent's level of knowledge and the respondent's perceptions about e-cigarettes, while the dependent variable was the respondent's vaping behavior. The data obtained described by being categorized as good, enough, and less of knowledge. Perception is categorized as positive and negative while vaping behavior is categorized into good and bad behavior. To find the correlation, each variable did not use an assessment based on category but instead used the respondent's full score with the Spearman's Rho test statistical data analysis. $\mathrm{P}<0.05$ indicates a significant relationship and the correlation coefficient value is identified to determine the strength of the relationship and the direction of the relationship. The positive direction of the 
relationship shows that the higher the independent variable is, the higher the dependent variable will be.

\section{RESULTS}

This study found there was a significant relationship between the level of respondent's knowledge and respondent's perceptions toward vaping behavior with a significance level of $<0.05$. It was also suggested that the correlation coefficient indicating the strength of the relationship was comparatively weak $(0.269)$ and moderate $(0.420)$ with a prospect of positive direction.

Table 1. Frequency Distribution of Demographic Characteristics and General Data of Respondents

\begin{tabular}{lcc}
\hline \multicolumn{1}{c}{ Variable } & $\begin{array}{c}\text { Frequency } \\
(\mathbf{n})\end{array}$ & $\begin{array}{c}\text { Percentage } \\
(\mathbf{\%})\end{array}$ \\
\hline Age (Mean \pm SD) & $21.20 \pm 1.92$ & \\
\hline Gender & 76 & $100 \%$ \\
Male & 0 & $0 \%$ \\
Female & & \\
\hline Usage Status & 29 & $38.2 \%$ \\
Move from & & \\
conventional cigarettes & 14 & $18.4 \%$ \\
Direct using e-cigarette & 14 & $43.4 \%$ \\
Dual user & 33 & \\
\hline Duration (Years) & & $1.3 \%$ \\
6 & 1 & $2.6 \%$ \\
5 & 2 & $3.9 \%$ \\
4 & 3 & $22.4 \%$ \\
3 & 17 & $17.1 \%$ \\
2 & 13 & $17.1 \%$ \\
1 & 13 & $28.9 \%$ \\
$<1$ & 22 &
\end{tabular}

Table 2. Variable Frequency Distribution

\begin{tabular}{lcc}
\hline \multicolumn{1}{c}{ Variable } & $\begin{array}{c}\text { Frequency } \\
\text { (n) }\end{array}$ & $\begin{array}{c}\text { Percentage } \\
\text { (\%) }\end{array}$ \\
\hline Knowledge level & & \\
$\quad$ Good & 16 & $21.1 \%$ \\
Enough & 20 & $26.3 \%$ \\
Less & 40 & $52.6 \%$ \\
Perception & & \\
$\quad$ Positive & 35 & $46.1 \%$ \\
$\quad$ Negative & 41 & $53.9 \%$ \\
Vaping behavior & & \\
$\quad$ Good & 39 & $51.3 \%$ \\
$\quad$ Bad & 37 & $48.7 \%$ \\
\hline Source: Primer data & &
\end{tabular}

Table 3. Results of Spearman's Rho analysis

\begin{tabular}{lcc}
\hline \multicolumn{1}{c}{ Spearman's Rho test } & $P$ value & R \\
\hline $\begin{array}{l}\text { Knowledge value - Vaping } \\
\text { behavior }\end{array}$ & $0.019^{*}$ & 0.269 \\
$\begin{array}{l}\text { Perception - Vaping behavior } \\
\text { P }<0.05 \text { indicates the significance of the relationship } ; R \text { (correlation } \\
\text { coefficient) }\end{array}$ & $0.000^{*}$ & 0.420 \\
\hline
\end{tabular}

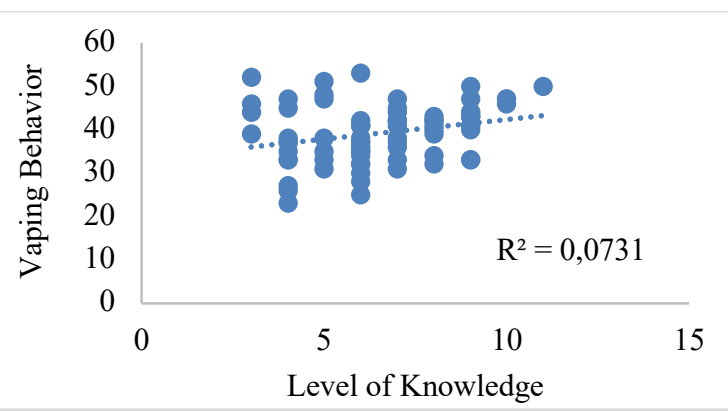

Figure 1. Knowledge Value Scatter Diagram of Vaping Behavior

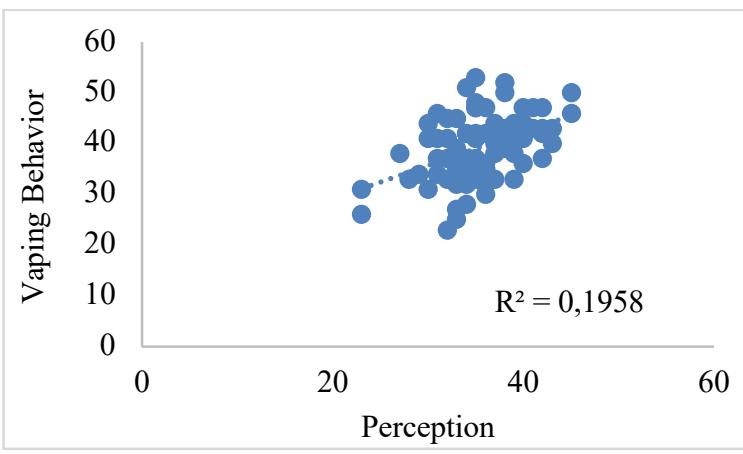

Figure 2. Perception Value Scatter Diagram of Vaping Behavior

\section{DISCUSSION}

The characteristics of the respondents in this study included age, gender, usage status, and length of time using e-cigarettes. The age range of respondents sampled in this research belongs to those of late adolescence (18-24 years of age) based on the Association of Maternal and Child Health Programs (2019). It is assumed that people belonging in the age range have a more mature understanding of their actions and are aware of their medical condition. Vaporizers taking part in this study were mostly aged 20 with a total of 18 respondents $(23.7 \%)$ with a mean and standard deviation of $21.20 \pm 1.92$. In this 
study, the total number of respondents was all 76 men. There was a significant relationship between gender and e-cigarette use in Indonesia, where males were found to be the most probable gender to use the e-cigarette. ${ }^{11}$

From the usage status, there were 14 (18.4\%) respondents who used e-cigarettes without a history of using conventional cigarettes. The use of e-cigarettes without a history of conventional smoking is a function of misuse of e-cigarettes as NRT or an alternative to quitting conventional smoking. Furthermore, there were 29 respondents (38.2\%) who used e-cigarettes because they switched from tobacco cigarettes and most of the respondents were dual users $33(43.4 \%)$ who used e-cigarettes without quitting tobacco cigarettes. From the data obtained, of all dual users, $60.6 \%$ used e-cigarettes because they wanted to stop and reduced the use of conventional cigarettes. However, stopping and reduce the use of conventional cigarettes requires a gradual process. ${ }^{12}$ The ratio of nicotine content in conventional cigarettes is higher than in e-cigarettes, making conventional cigarette users who want to reduce or stop smoking are not satisfied enough if they only use e-cigarettes. So most of them use both. In fact, dual users without reducing the use of conventional cigarettes will increase the risk of harm, and even though it is used also with a reduction in the use of conventional cigarettes does not prove to have many health benefits. E-cigarettes do not reduce the cause of death, the incidence of cardiovascular disease, and even cancer. However, e-cigarettes can reduce the risk of lung cancer. ${ }^{13}$

In terms of the length of time using ecigarettes, of the 76 respondents the highest use was less than one year by 22 respondents
$(28.9 \%)$ and only 1 respondent $(1.3 \%)$ with the longest use, starting from 2013 or approximately 6 years. This signifies that the use of e-cigarettes is increasing from year to year. According to the 2016 National Health Indicator Survey, the prevalence of ecigarette use jumped to $10.9 \%$ from 2015 to 2016. Moreover, in July 2018, the government legalized e-cigarettes so that users felt that its use was safe. The government legalized e-cigarettes by imposing expensive excise fees to control its use in Indonesia. However, the safety of ecigarettes remains unclear as e-cigarettes have been failed to meet safety standards. ${ }^{10}$

As many as 40 respondents $(52.1 \%)$ showed that they had inadequate knowledge about ecigarettes. The low level of knowledge about e-cigarettes is due to the lack of information about e-cigarettes in Indonesia, as well as the lack of socialization by health agencies regarding the content and impact of ecigarettes. The low level of knowledge can also be attributed to the demographics of this research's location that is Bangil District which is a non-urban area in which factors relating to people's knowledge are not optimal. These factors include education, information/mass media, socio-culture and economy, environment, experience, and age. $^{14}$

This study also shows that most respondents had wrong or negative perceptions about ecigarettes indicated by 41 respondents $(53.9 \%)$. The average user has negative perceptions such as supporting the use of cigarettes. ${ }^{15}$ Individual perceptions do not come naturally but go through several processes and factors that influence each person's perception. Perception is a process of receiving information and messages as a 
stimulus to be processed in the brain of each individual. ${ }^{16}$ Thus, the lack of information regarding the content contained in liquid and the safety of using cigarettes will render respondent's perceptions inappropriate for cigarettes. ${ }^{15}$ The effort that can be done is to make regulations regarding warning labels on all tobacco products including cigarettes to clarify existing perceptions regarding that. ${ }^{17}$

Many users perceive e-cigarettes are safer than their conventional counterparts. However, until now the safety of e-cigarettes is still contentiously debated, whether it can reduce nicotine use because it is safer or increase the danger. In 2019, the CDC reported an outbreak of e-cigarette, or vaping, product use-associated lung injury (EVALI) in 50 US states. ${ }^{18}$ The clinical manifestations are symptoms of the respiratory system such as coughing, shortness of breath, and chest pain. ${ }^{18}$ Other symptoms are from the gastrointestinal system such as nausea, vomiting, abdominal pain or diarrhea, and other nonspecific symptoms, like fever, weight loss, and weakness. As many as $82 \%$ of EVALI cases were caused by tetrahydrocannabinol (THC) -containing products and $57 \%$ due to the nicotine contained. ${ }^{19}$ However, it does not rule out the possibility of other chemical substances also affecting the occurrence of this outbreak. In a study conducted by Leyden et al (2019), patients with EVALI cases found $91 \%$ abnormalities on chest radiographs and $100 \%$ on $\mathrm{CT}$ scans. The data above show that e-cigarettes are not as safe as the majority believe them to be. ${ }^{20}$

The factors that influence a person's vaping behavior are determined by knowledge, attitudes, beliefs or perceptions, traditions, and any other internal factors that an individual demonstrates. ${ }^{12}$ Based on the results of the study, 39 of the 76 respondents (51.3\%) had good vaping behavior and the rest are the opposite. The cause of using ecigarettes in adolescents is due to trial and error behavior. ${ }^{21}$ Another cause that affects vaping behavior is the rejection of ecigarette's danger for health, as well as the existence of peer groups and family members who use them.

The correlation results based on the statistical test of Spearman's Rho show that there is a relationship between knowledge and vaping behavior, but the correlation is weak. Good knowledge will be a protective factor for a person from heavy use of e-cigarettes (bad behavior). ${ }^{12}$

The results of statistical analysis using Spearman's Rho showed that there was a moderate relationship between perception and vaping behavior. The results of the analysis with diagram scatter obtained a coefficient of determination of 0.1958 , which means that the perception contributes to vaping behavior was $19.6 \%$. This is different from knowledge which only affects behavior by $7 \%$. Beliefs/perceptions have a greater contribution to a person's behavior and change in behavior than the level of knowledge. ${ }^{22}$

E-cigarettes are no longer recommended by the FDA as NRT, due to the fact that ecigarettes also have dangers for their users. According to the National Institute of Health, a way that may be effective is to carry out treatment through counseling with behavioral support. ${ }^{4}$ The results of the study show that the average teenager who uses ecigarettes is still lacking knowledge and has 
a wrong perception about e-cigarettes. Lack of information is one of the contributing factors, therefore overcoming this problem requires government efforts to provide regulations on e-cigarettes, such as labeling hazard warnings and providing education or socialization to the wider community about e-cigarettes. Because e-cigarettes can become a health problem in the future if not properly overcome at this time.

\section{CONCLUSION}

There is a significant relationship with a weak positive correlation coefficient between the knowledge of e-cigarettes on vaping behavior and there is also a significant relationship with a moderate positive correlation coefficient between the perception of vaping behavior among adolescent users in Bangil District. It can be found that there were still many misuses in the function of e-cigarettes as NRT in adolescents such as using them without a previous history of conventional smoking. Not all dual users used e-cigarettes to quit or reduce the use of conventional cigarettes, this bad behavior can be a risk factor for increased health problems.

\section{ACKNOWLEDGMENT}

The researcher would like to thank the owners of the Sekawan Cafe, Coklat Banget, and the Vape shop who have allowed and helped the researcher to find respondents.

\section{REFERENCES}

1. Cobb NK, Byron MJ, Abrams DB, et al (2010). Novel nicotine delivery systems and public health: the rise of the "ecigarette". Am J Public Health, 100(12), 2340-2342

2. Bunnell RE, Agaku IT, Arrazola RA, et al (2015). Intentions to smoke cigarettes among never-smoking US middle and high school electronic cigarette users: National Youth Tobacco Survey, 20112013. Nicotine Tob Res, 17(2), 228-235

3. Jamal A, Gentzke A, Hu SS, et al (2017). Tobacco Use Among Middle and High School Students - United States, 20112016. MMWR Morb Mortal Wkly Rep, 66(23), 597-603

4. U.S. Food \& Drug Administration (FDA) (2019). Vaporizers, E-cigarettes, and other Electronic Nicotine Delivery Systems (ENDS). Available at https://www.fda.gov/tobacco-products/ products-ingredients-components/ vaporizers-e-cigarettes-and-otherelectronic-nicotine-delivery-systemsends. Accessed June 26, 2019

5. U.S. Department of Health and Human Services, Centers for Disease Control and Prevention, National Center for Chronic Disease Prevention and Health Promotion, Office on Smoking and Health (2016). E-Cigarette Use Among Youth and Young Adults: A Report of the Surgeon General-Executive Summary. Available at https://ecigarettes.surgeongeneral.gov/document s/2016_SGR_Exec_Summ_508.pdf.

Accessed June 18, 2019

6. Offermann FJ (2015). Chemical emissions from e-cigarettes: Direct and indirect (passive) exposures. Building and Environment, 93, 101-105

7. Lerner CA, Rutagarama P, Ahmad T, et al (2016). Electronic cigarette aerosols and copper nanoparticles induce mitochondrial stress and promote DNA fragmentation in lung fibroblasts. 
Biochem Biophys Res Commun, 477(4), 620-625

8. Goniewicz ML, Knysak J, Gawron M, et al (2014). Levels of selected carcinogens and toxicants in vapour from electronic cigarettes. Tob Control, 23(2), 133-139

9. Miech R, Patrick ME, O'Malley PM, et al (2017). E-cigarette use as a predictor of cigarette smoking: results from a 1year follow-up of a national sample of 12th grade students. Tob Control, 26(e2), e106-e111

10. Indonesian Food and Drug Authority (BPOM RI) (2015). InfoPOM, 16(5)

11. Elsa MS, Nadjib M (2019). Determinan rokok elektrik di Indonesia: data SUSENAS (Survei Sosial Ekonomi Nasional) tahun 2017. Berita Kedokteran Masyarakat, 35(2), 41-48

12. Damayanti A (2016). Electronic cigarette using in Surabaya's personal vaporizer community. Jurnal Berkala Epidemiologi, 4(2), 250-261

13. Pissinger $C$ (2015). A systematic review of health effects of electronic cigarettes. Available at https://www.who.int/ tobacco/industry/product_regulation/Ba ckgroundPapersENDS3_4November.pdf. Accessed January 2,2019

14. Budiman, Riyanto A (2014). Kapita Selekta Kuesioner Pengetahuan dan Sikap dalam Penelitian Kesehatan. Jakarta: Salemba Medika

15. Putra IGNE, Putra IMR, Prayoga DGAR, et al (2017). Gambaran pemahaman, persepsi, dan penggunaan rokok elektrik pada siswa sekolah menengah atas di Kota Denpasar (knowledge, perception, and e-cigarette use among senior high school students in Denpasar city). Research Gate. Proceeding Book $4^{\text {th }}$ ICTOH 2017
16. Slameto (2003). Belajar dan FaktorFaktor yang Mempengaruhinya. Jakarta: Rineka Cipta

17. Romijnders KAGJ, van Osch L, de Vries $\mathrm{H}$, et al (2018). Perceptions and Reasons Regarding E-Cigarette Use among Users and Non-Users: A Narrative Literature Review. Int j Environ Res Public Health, 15(6), 1190

18. Centers for Disease Control and Prevention (CDC) (2019). New cases in outbreak of e-cigarette, or vaping, product use-associated lung injury (EVALI) on the decline. Available at https://www.cdc.gov/media/releases/20 19/p1220-cases-EVALI.html. Accessed January 18, 2019

19. Centers for Disease Control and Prevention (CDC) (2020). Smoking \& tobacco use: Outbreak of lung injury associated with e-cigarette use, or vaping. Available at https://www. cdc.gov/tobacco/basic_information/ecigarettes/severe-lung-disease.html. Accessed January 18, 2019

20. Leyden JE, Ghinai I, Pray I, et al (2019). Pulmonary illness related to e-cigarette use in illinois and wisconsinPreliminary report. N Engl J Med, 382(10), 903-916

21. Devhy NLP, Yundari AAIDH (2017). Faktor yang berpengaruh terhadap perilaku merokok konvensional dan elektrik pada remaja di Kota Denpasar. Bali Medika Jurnal, 4(2), 63-72

22. Fishbein M, Ajzen I (2010). Predicting and changing behavior: The reasoned action approach. New York: Psychology Press (Taylor \& Francis) 